\title{
Applying a participatory methodology to evaluate ecosystem services in the Pampa biome: lessons learned from the Tessa methodology in Uruguay
}

\author{
Aplicación de metodología participativa para evaluación \\ de servicios ecosistémicos en el bioma Pampa: \\ lecciones aprendidas del método Tessa en Uruguay
}

\author{
Daniela Schossler ${ }^{1}$ \\ Carlos Nabinger ${ }^{2}$ \\ Claudio Ribeiro $^{3}$ \\ Pablo Boggiano ${ }^{4}$ \\ Monica Cadenazzi ${ }^{5}$
}

Diana L. Restrepo-Osorio ${ }^{6}$

${ }^{1}$ Master's Degree in Soil and Water Management and Conservation, PhD candidate, Department of Animal Production and Pastures, Faculty of Agronomy, University of the Republic of Uruguay, Paysandú, Uruguay E-mail: tessapilotobrasil@gmail.com

2 PhD in Animal Science, Professor, Department of Forage Plants and Agrometeorology, Faculty of Agronomy, Universidade Federal do Rio Grande do Sul, Porto Alegre, Brazil

E-mail:nabinger@ufrgs.br

${ }^{3}$ PhD in Rural Development, Professor, Universidade Federal do Pampa, Bagé, Brazil E-mail: claudioribeiro@unipampa.edu.br

${ }^{4}$ PhD in Animal Science, Professor, Department of Pastures, Faculty of Agronomy, University of the Republic of Uruguay, Paysandú, Uruguay E-mail: prboggia@fagro.edu.uy

${ }^{5}$ PhD in Animal Science, Professor, Department of Pastures, Faculty of Agronomy, University of the Republic of Uruguay, Paysandú, Uruguay E-mail:monicade@fagro.edu.uy

${ }^{6}$ PhD in Geography, The University of Kansas; United States Geological Survey (current affiliation), Kansas Water Center (USGS KWSC), Lawrence, Kansas, USA E-mail: restrepita.diana@gmail.com 


\section{ABSTRACT}

Identifying and measuring ecosystem services involving local stakeholders has been characterised as a novel approach in the literature. This article describes the methodology used in the participatory workshops, the lessons learned, and the specific results of applying the Tessa method. The methodology was piloted with 56 researchers and technicians, more than 22 institutions, and 54 livestock producers involved with the grassland conservation initiative, Alianza del Pastizal. Identified change agents with the most significant impact include the absence of a rural workforce, the lack of family succession, and weeding and overgrazing of grasslands. The primary ecosystem services identified included the production of fodder, meat/wool, wildlife forage, way of life/culture, and medicinal plants. The methodology presented here is replicable, capable of expansion to more groups, contributes to a better understanding, by the producers, of their problems and points to the need for the development of public incentive policies.

Keywords: Extensive livestock farming. Ways of life. Sociocultural perceptions. Native grasslands. Incentive-based policies. Conservation.

\section{RESUMEN}

Identificar y medir servicios ecosistémicos involucrando actores locales tiene carácter novedoso en la literatura. El artículo describe el método utilizado en los talleres participativos, las lecciones aprendidas y los resultados específicos de la aplicación del método Tessa. La metodología fue aplicada de forma piloto con 56 investigadores y técnicos, más de 22 instituciones y 54 productores ganaderos involucrados con la iniciativa de conservación de campo natural, Alianza del Pastizal. Los agentes de cambio con mayor impacto, apuntados por los participantes, fueron la ausencia de trabajadores rurales, la falta de sucesión familiar, el enmalezamiento y sobrepastoreo de los campos. Los principales servicios ecosistémicos, producción de forraje, carne/lana, alimentación para fauna silvestre, modo de vida/cultura y plantas medicinales. La metodología es replicable, capaz de ser expandida a más grupos aportando al mejor conocimiento por parte de los productores de sus problemas y apuntando para la necesidad de desarrollo de políticas públicas de incentivo.

Palabras clave: Ganadería extensiva. Modo de vida. Percepción sociocultural. Campo natural. Políticas de incentivo. Conservación.

\section{INTRODUCTION}

The concept adopted worldwide for ecosystem services (ES) is anthropogenic: "benefits provided by ecosystems to humans" (MEA, 2005, p. 23). However, in developing public policies, local stakeholders, the primary beneficiaries and maintainers of the ecosystem, do not always have a central and omnipresent role in discussing important issues. This approach emphasises the role of culture in defining all links between people and nature (DÍAZ et al., 2018).

South American natural temperate and subtropical fields, which are spatially heterogeneous (BERRETTA et al., 2000), constitute the primary forage base of Uruguay. It is the most important nutritional resource for cattle and sheep breeding and includes one of the most critical assets in terms of biodiversity (MGAP, 2012). A diversity of species coexists in grazing contexts and depends on it to remain productive and existing. This combination provides a range of valuable ecosystem services that affect human wellbeing (VIGLIZZO; FRANK, 2006; WEYLAND et al., 2017).

Identifying ecosystem services with participatory methodologies involving users and beneficiaries of natural fields is novel in the literature. According to the analysis made by Castillo (2019, p. 120), publications on the SE thematic and social dimensions, specifically "giving voices to different actors", are scarce in South America. Most research (61\%) lacks the inclusion of local actors; of that, only $13 \%$ address the agents of change (causes/factors of alteration of the natural ecosystem). 
The Toolkit for Ecosystem Service Site-Based Assessment (Tessa) provides accessible guidance for low-cost methods to assess the benefits people receive from nature at particular sites to generate information that can be used to influence decision-making (PEH et al., 2017). However, it does not have defined protocols for rural ecosystems or proposed a method for identifying and involving stakeholders.

The Tessa methodology was first applied in the countryside ecosystem in Brazil in the year 2016 by Schossler (2016), then Argentina (SCHOSSLER et al., 2016a), Paraguay (SCHOSSLER et al., 2016b) and then Uruguay between the years 2016 and 2020 funded by BirdLife International. The lessons learned in this article result from applying the method in participatory workshops in the four countries with 56 researchers involved with the SE and social dimensions thematic, more than 22 institutions and 54 participating producers associated with the Alianza del Pastizal.

The Alianza del Pastizal (AP), an initiative to promote sustainable livestock farming, works to preserve natural pastures, also called temperate grasslands, among livestock farming communities in Uruguay, Paraguay, Argentina, and Brazil. One of the projects they promote is the certification of estates with at least $50 \%$ of the area with natural grasslands in a good state of conservation (PARERA et al., 2014).

The objectives of the article are a) to describe the method used in the participatory workshops for the assessment of ecosystem services and agents of change as a basis for the development of the Tessa methodology; b) to disseminate the lessons learned in the pilot workshops in the four countries; c) to report the results of the case study in Uruguay.

\section{METHODOLOGY}

\subsection{IDENTIFICATION OF STAKEHOLDERS}

In February 2016, a pilot workshop was held with professionals and technicians working with natural grasslands to inform and evaluate the Tessa methodology in Uruguay. In addition, the tools and characteristics that were necessary for the selection of the study sites were also discussed.

The study "site" was defined as the management unit or potential study unit. The possible area can be protected, identified as necessary from a biodiversity point of view. The site should be an operational or potential management unit, such as a protected area or an area important for birds and biodiversity. It generally ranges in size from 100 to 100,000 ha, with boundaries established by stakeholders.

For the site selection, we used the historical environmental certifications based on the Grassland Conservation Index (ICP), which were developed by the Alianza del Pastizal (PARERA et al., 2014). Data from 215 certified farms in Uruguay were evaluated. Properties with the most representative ICP ranges in the country were chosen. These were located close to each other, in a landscape of biological importance, with similarities of fields, land use, and producers as ranchers in natural grasslands. Based on these criteria, Colonia Juan Gutiérrez was chosen, which had 30 certified properties organized in the Sociedad de Fomento de la Colonia Juan Gutiérrez (SFCJG).

\subsection{URUGUAY CASE STUDY: CHOOSING THE ACTORS}

Colonia Juan Gutiérrez (CJG) is located between the latitudes of 320 12,554' and 320 7,530' South and the longitudes of $57015,198^{\prime}$ and 570 26,308' West. It is in the department of Paysandú and the city of Guichón. CJG has an area of 8,300 hectares and approximately 30 properties, most of which practice cattle ranching, with an average of 300 hectares per property. The properties' fields belong to the National Institute of Colonization (INC), and the producers are tenants and must follow the INC criteria. 
The Colonia is located at the confluence of the Queguay Grande and Queguay Chico rivers, where the Montes del Queguay Managed Resource Protected Area is located (Figure 1). The boundaries of the protected area are defined by the limit of the potential flooding surface. The area was valued for entry into the National System of Protected Areas (Snap) for its environmental diversity highlighting its uniqueness and low degree of intervention. This area also has elements of interest for protecting the ecosystem and priority species for conservation (MEDINA et al., 2019). The Snap protects producers with the presence of a park ranger.

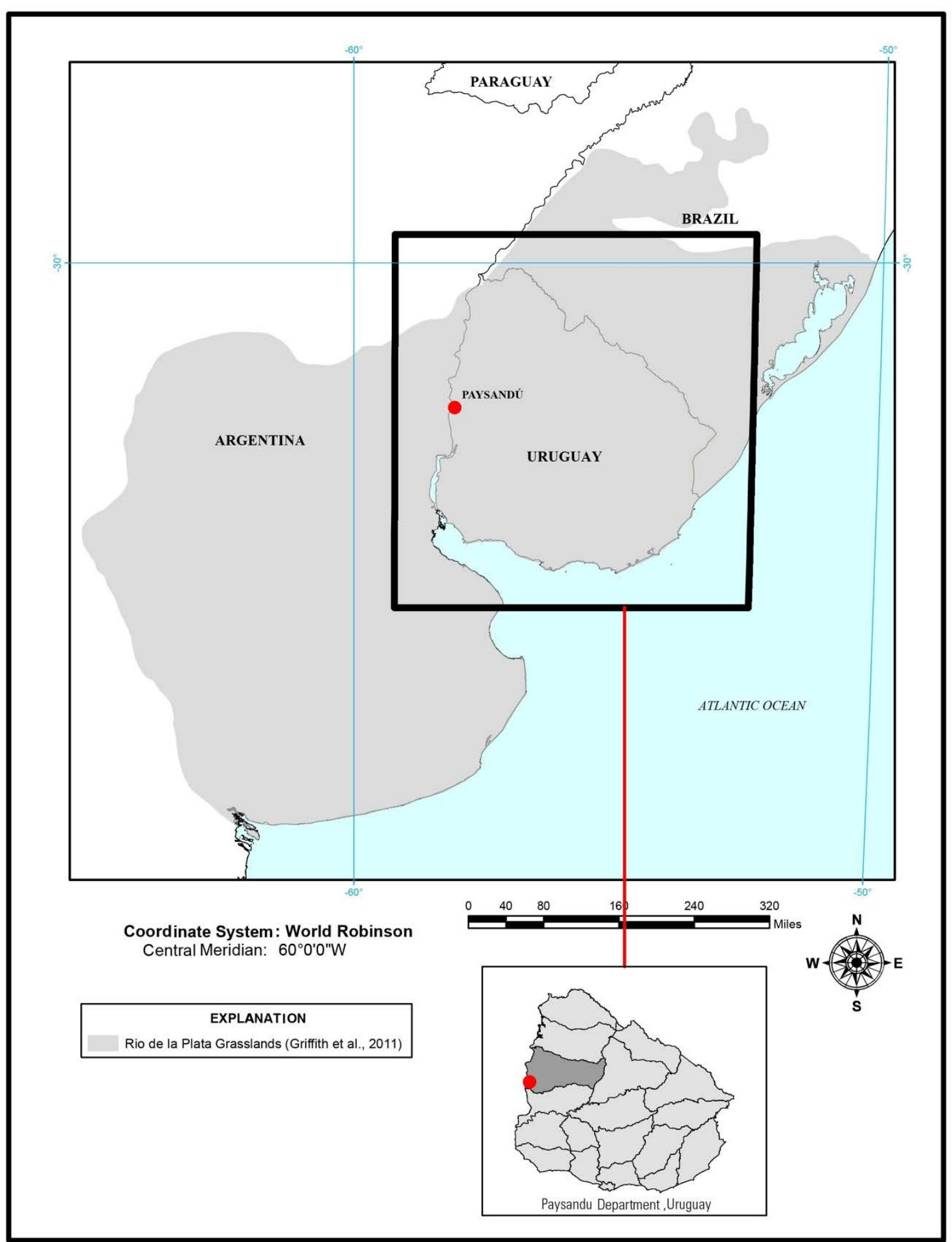

Figure 1 - Location of the study area, Colonia Juan Gutiérrez, Guichón, Department of Paysandú, Uruguay. In gray the location of the Río de la Plata grasslands. 
The SFCJG, founded in 1975, is an association of producers, where each participant maintains legal independence and managerial autonomy and takes part voluntarily in a joint effort (BÁEZ, 2005).

The Instituto Plan Agropecuario supports, articulates and develops projects with the CJG and other institutions (MACHÍN, 2019) such as the Instituto Nacional de Investigación (Inia), the Ministerio de Ganadería Agricultura y Pesca (Mgap) and, the Comisión Nacional de Fomento Rural, all of this supported by the SFCJG legal entity.

The Alianza del Pastizal has historically collaborated with the producers of Colonia. In 2014, the Inter-American Development Bank (IDB) financed a project where 30 CJG farms were certified with the ICP. In addition to that initiative, between 2013 and 2017, Inia and New Zealand developed the "Uruguay Family Farm Improvement Project" titled "Improving the Sustainability of Family Farming in Uruguay" to evaluate the ICP at the start and the end of the project.

\subsection{TESSA GUIDE STEPS}

This article discusses the execution of the "Preliminary Scoping Assessment", which is step 2 of the Tessa method (Figure 2). This step addresses the questions: a) What will change in the ecosystem services because of management decisions, and b) What impact will this have on different groups of producers according to the benefits the chosen site confers? 


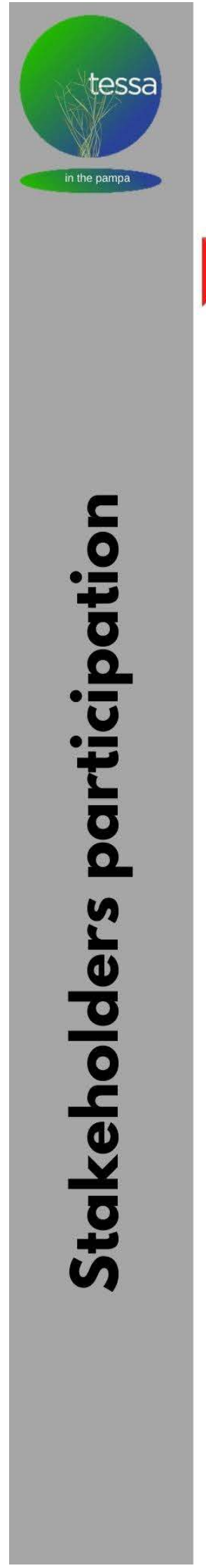

\section{Step 1.}

Preparation

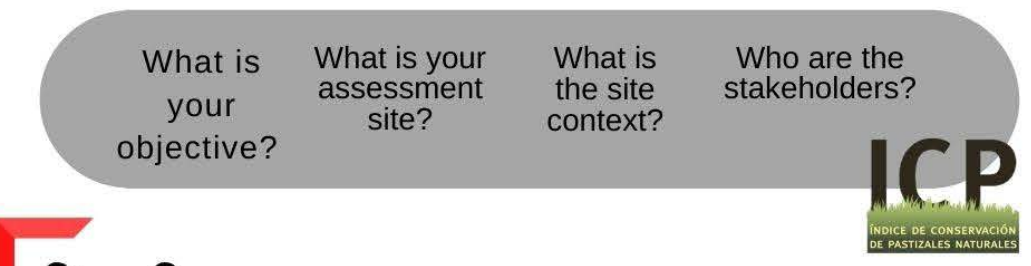

\section{Step 2.}

Preliminary scoping appraisal

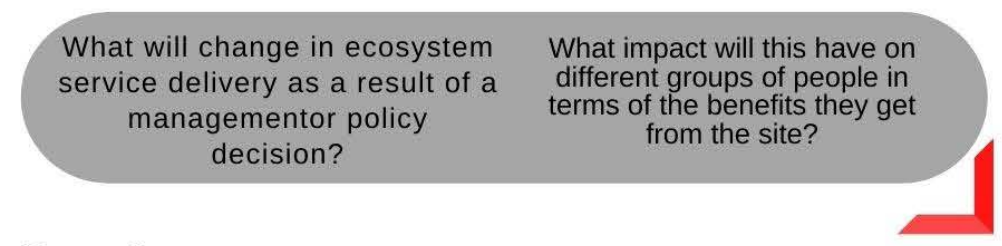

\section{Step 3.}

Determine the alternative state

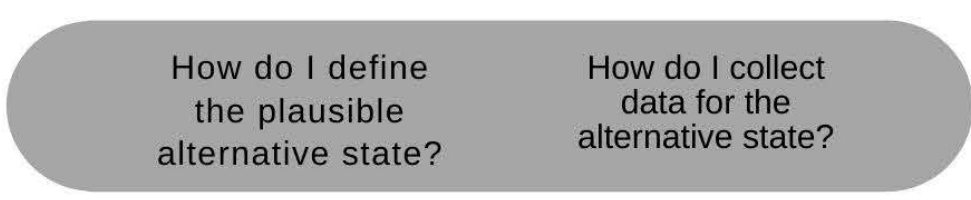

\section{Step 4.}

\section{Planning the full assessment}

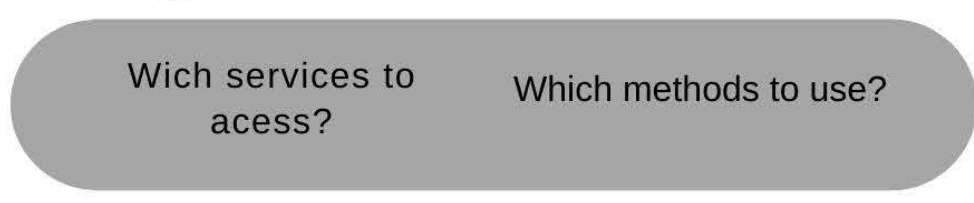

\section{Step 5.}

Collect data at the assessment and comparison site

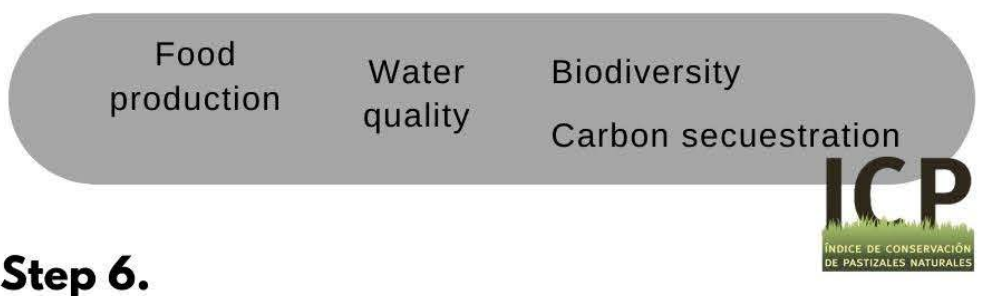

Analyse and communicate the results

Presenting and Communicating results

Figure 2 | Steps of the Tessa method in the pampas and the use of the Grassland Conservation Index (Step 1 and 5). 
The expected results identify the ES that will be evaluated in the field and make it possible to answer the questions for the next methodological steps (Step 5).

\subsection{PARTICIPATORY WORKSHOPS METHODS}

The method adopted for the workshops had three main steps: first, the presentation and sensitisation on the central theme of "ecosystem services"; the second step is the group exercises described below, and the third step is the discussion and generalisation of the relevant information arising from the workshop.

The information generated was compiled and evaluated, and easy-to-interpret graphs where stakeholders can quickly identify their perceptions were generated. Hypothetical changes in ecosystem services and their distribution under an alternative state (if the targeted threats are established, e.g., change due to agriculture) were compared. The results were then interpreted about possible management strategies.

\section{Step 1: Presentation and raising awareness}

A brief explanation of approximately 30 minutes was given in empathetic and straightforward language on the concept, classification, and examples of ecosystem services in natural grasslands.

Step 2: Group exercises: descriptions and tables used to identify agents of change and ecosystem services.

Producers are divided into small groups of up to 5 , and each group completes the basic Tessa information table (completing parts 1 and 2 described below). Worksheets are provided with an explanation of the steps to follow with tables to fill out (Table 1). Additionally, a map of a representative property of the study area (in which the participating stakeholders are included) is distributed. This map contains the total area and area according to soil type, paddocks, and current use.

The first step is to identify the area occupied by each vegetation cover/use since many ecosystem services are provided at the habitat level and are directly associated with the type of vegetation cover. Then, a classification of the main habitats is completed using the information on the type and percentage of the system occupied.

\section{Identification of threats and agents of change}

In addition to identifying threats and agents of change, the impact of management policies, possible actions for change on some producers and institutions, and management policies and positive actions on some individuals and institutions were estimated. 


\section{Identification of agents of change (threats)}

\begin{tabular}{|c|c|c|c|c|}
\hline $\begin{array}{l}\text { Threats } \\
\text { of the site } \\
\text { (pressures) }\end{array}$ & $\begin{array}{l}\text { Time (next } \\
10 \text { years) } \\
\text { More than } 4 \text { years } \\
\text { 2. Within } 4 \text { years } \\
\text { 3. Now }\end{array}$ & $\begin{array}{l}\text { Scope (proportion } \\
\text { of the site } \\
\text { that is affected) } \\
\text { 1. Small area } \\
\text { 2. Some of the area } \\
\text { 3. Most of the area }\end{array}$ & $\begin{array}{l}\text { Severity (e.g., degree of } \\
\text { of habitat degradation } \\
\text { habitat, size of } \\
\text { of effect) } \\
\text { 1. Low } \\
\text { Moderate } \\
\text { 3. High }\end{array}$ & $\begin{array}{c}\text { Impact } \\
\text { (Time + Scope } \\
+ \text { Severity })\end{array}$ \\
\hline \multicolumn{5}{|c|}{ Identification of ecosystem services (benefits) } \\
\hline Benefits & $\begin{array}{l}\text { Current Status (Score } \\
\qquad \begin{array}{l}0-5 \text { ) } \\
5=\text { very important }\end{array}\end{array}$ & $\begin{array}{c}\text { Five prioritized } \\
\text { services in current } \\
\text { status }\end{array}$ & $\begin{array}{l}\text { Alternative status } \\
\quad \text { (Score 0-5) } \\
5 \text { = very important }\end{array}$ & $\begin{array}{l}\text { Five services } \\
\text { prioritized in the } \\
\text { alternative state }\end{array}$ \\
\hline
\end{tabular}

\section{Characterization of the main ecosystem services}

\begin{tabular}{ccccc}
\hline $\begin{array}{c}\text { Benefits (5) } \\
\text { prioritized }\end{array}$ & Who benefits? & How has availability & How will this benefit & What are the \\
from table 2 & Global & change in the & main agents of \\
& & Lears? & alternative state? & change \\
& 1. little increase & Large increase & (cause/factor) of \\
& 0. no change & 1. little increase & this change? \\
& -1. Little decrease & -1. Little decrease
\end{tabular}

Table 1| Tables used in the workshops to identify agents of change (threats), current and alternative state ecosystem services and characterise likely future changes.

Source: Created by author

The first step is completed by estimating possible short- and medium-term decision outcomes, meaning10 years from now, and caused by current trends at the site without any intervention to mitigate those trends. The estimation of outcomes should consider a) the current and potential agents of change for the site in short to medium term (now or in the next 10 years); b) how immediate are these changes; c) how likely are these changes to occur?; d) what is the extent of these changes to the habitats and biodiversity of the site in terms of area and what will be the magnitude of the change (extent); e) how will these agents of change affect the habitats and biodiversity of the site in terms of the magnitude of effect? (e.g., degree of habitat degradation, size of effect). This last scenario is referred to as the "alternative state".

In the alternative state or change scenario, it is necessary to emphasise the productive, social, ecological, and economic benefits of altering the current state. Evaluating a particular ecosystem service is a practical step to know the benefits it provides to people. Still, it is essential to understand the social, ecological, and economic consequences of changing its current (conserved) state compared to a plausible alternative. An alternative form may be the replacement of the natural grassland by agriculture or restoring the present natural grassland, using various management plans and improvements by adding agricultural inputs. Impact assessments resulting from changes in land use may be more helpful to decision-makers than single state values. Comparative estimations can directly impact biodiversity and ecosystem services, and they can also provide information on who is affected (PEH et al., 2013). 


\section{Ecosystem services identification}

A sheet is provided with a brief explanation of what ES are, their classifications and beneficiaries. Participants start the process by identifying all the benefits provided by natural grasslands in the study region. It is necessary to define and identify the ecosystem services provided by the focus areas to evaluate the range of ecosystem services provided by the sites at all scales. This exercise also allows for the potential contributions of the identified ES at the national and global levels. Table 2 was used for this purpose, where, in the first column, all the benefits are rated from 0-5. $0=$ not relevant, $1=$ of little importance, 5 = very important. Then, from the highest-scoring benefits in the list, five priority benefits are agreed upon for the site in its current state. The second step is to do the same for the alternative state (if the threats noted above influenced the site) by identifying the benefits provided in the alternative state and their importance, measured on the same scale of 1 to 5 . As before, five priority benefits are identified for the alternative state.

Step 3: Plenary discussion to select the most critical ecosystem services.

Characterisation of the primary ecosystem services, their beneficiaries, likely changes, and agents of change.

Using the group discussion methodology, the primary services that emerged from the group work were determined. Special attention was paid to the ideas of non-repetition and complementation of services: which were more important? which were repeated or complementary? The questions of this step were explained, and the answers were completed during the plenary.

It is essential to ensure that in the quantification of ES, there is no double counting. This could occur if the processes and services and the final products are all considered additive components. For example, the value of pollination and crop pest regulation is beneficial processes that manifest through increased food production (a benefit). Therefore, if the value of food production itself is accounted for, crop pollination and pest regulation should not be valued aggregated independently. This additive criterion makes it possible to generate a model free of duplicates and considering that only additive criteria are entered (BALMFORD et al., 2011).

At this stage, it is essential to finalise the collected information and generate group discussions to arrive at the crucial benefits and threats and obtain trends and possible future changes.

The objective of this step is to be able to explain a model with the best possible cost/benefit ratio.

\subsection{PARTICIPATORY WORKSHOPS}

\section{Pilot workshop with researchers and technicians}

The workshop series involved 13 different institutions and was facilitated by 18 instructors, researchers, and disseminators in natural grasslands. As a result, the objectives of the Tessa method were achieved, allowing for the subsequent definition of research foci and information dissemination in the study area. Furthermore, with a duration of 4 hours, the objectives of methodological adequacy for the following work with producers of the research focus were met.

\section{Workshop with local livestock producers}

This workshop was held with 12 traditional livestock producers from Colonia Juan Gutiérrez, instructors from the Faculty of Agronomy of the University of the Republic of Uruguay, Snap representatives, the administrator and director of the protected area, and the president of the SFCJG. The objective of this second workshop was to learn about the perception of the users and keepers of the selected study site. 


\section{RESULTS AND DISCUSSION}

\subsection{MAIN THREATS TO NATURAL GRASSLAND CONSERVATION, TRENDS IN DELIVERY AND LIKELY CHANGES}

The perception of ranchers and researchers was shown to be strongly influenced by their experiences with nature, sense of place, and its benefits (CORTÉS-CAPANO, 2020; FAGERHOLM et al., 2020; GOLDSTEIN et al., 2012; RAYMOND et al., 2016; TALLIS; POLASKY, 2009). By recognising the interdependencies between livestock production and ecological systems, the agents of change identified (Figure 3 ) in this work are linked to the landscape chosen for the study. These results align with similar participatory studies (CORTÉS-CAPANO, 2020; FORMOSO et al., 2020) done in Uruguay, which allows for the extrapolation of the information to other territories.

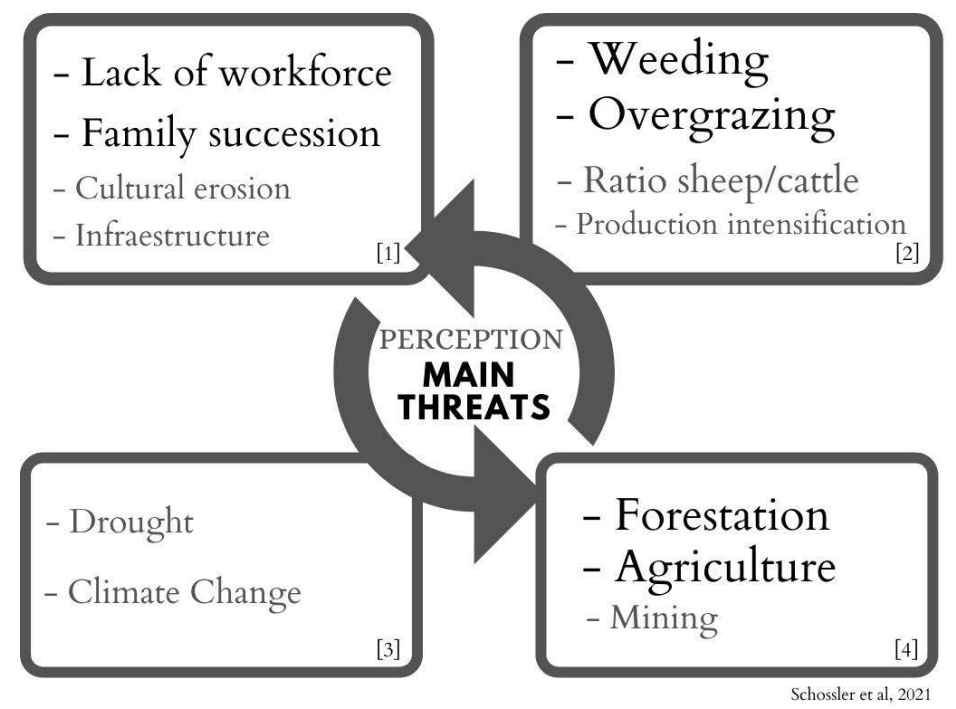

Figure 3 | Perception of the actors involved in the workshops regarding the main threats to the conservation of Uruguay's natural fields and grouped by similarity, where the agents of change with the highest degree of

\section{importance are highlighted.}

Source: Created by author

The first group [1] is characterised by social issues, where the absence of a rural workforce and the lack of family succession have the most significant impact on the rural population. Producers cite farm size (land division by inheritance), land tenure, and the ageing of the rural population as primary factors for these threats.

Landscape-supported well-being is related to multiple, or lack thereof, interconnected elements that can inform collective visions of well-being in the future (FAGERHOLM et al., 2020). The participant groups highlight their concern with cultural erosion (characterised by the loss of occupations), depopulation in the countryside, and the devaluation of one's own culture. Although these results predate the pandemic, likely, the way of life of these cattle ranching communities did not change. Therefore, these ranching families could have served as psychological and environmental refugees, given that Uruguay has a high rural population, which according to the world report on happiness the well-being per person, as well as the average well-being and life expectancy have increased in 2021 compared to the years 2006-2008 (HELLIWELL, 2021).

Changes in the provision of ES can have very different impacts on individuals within a community because access to and control of resources, and alternatives, is determined by factors like land ownership, gender, culture, ethnicity, and social status (DAW et al., 2011). In addition, structural problems appear 
to have a high impact on conservation, although these are associated with a lack of incentives to the sector. What characterises this is the lack of electricity, connectivity, and road conditions, also cited as threats by Formoso et al. (2020, p. 59).

Biodiversity conservation objectives in this cultural landscape cannot be pursued independently of social development objectives (CORTÉS-CAPANO, 2020). Factors affecting production such as weeding and overgrazing [2] are essential to stakeholders, although these are typical responses to management challenges and historical grassland use problems. At the national level, the GEO Report on State and Perspectives of the Environment in Uruguay indicated in 2009 that $30 \%$ of the country's territory suffered some degree of erosion where crops like soybean, rice, and corn are responsible for $87 \%$ of the eroded areas, and overgrazing for $12 \%$ (PÉREZ, 2020).

At the landscape scale, the excessive presence of some undesirable plant species is of concern to producers and technicians. The following species were cited, in order of importance for the weeding/ weediness of the field and consequent drop in livestock productivity: Bacharis coridifolia (myo-mio), Eryngium horridum (cardilla), Eupatorium buniifolium (chirca), Baccharis trimera (carqueja) and Heimia salicifolia (quiebra arados). Cited as weeds, they are native fields and cannot be confused with invasive exotic species (CEEI, 2014); their threat is not characterised by presence but by frequency, therefore, the number of species per square meter.

On a larger scale, land-use change has a high impact due to forestation (RESTREPO-OSORIO, 2020) and intensive agriculture [3]. Mining was another activity that emerged; however, according to the actors involved, it is not so worrying. Nevertheless, the identification of drivers (direct and indirect) that affect ES (DíAZ et al., 2015) is urgent given that the grasslands of the Río de la Plata are some of the fastest agricultural expansions not only in Latin America but in the world (BAEZA; PARUELO, 2020) This factor makes it one of the most modified biomes around the globe (BALDI; PARUELO, 2008; HANNAH, 1995; PARUELO, 2007).

External factors, no less important, such as drought and climate change [4], are perceived as threats and join the possibility of an increase in extreme climatic events with the forecast of a 1.5-degree increase in temperature (IPCC, 2021). This is predicted to occur ten years earlier than expected, which is believed to cause a greater frequency and/or intensity of some meteorological and climatic phenomena (IPCC, 2021). However, on the other hand, these factors could encourage natural grasslands production due to resilience and resistance (NABINGER et al., 2009).

Two aspects resulting from the main threats are the reduction of the pastoral area, given that today the remaining grasslands in Uruguay occupy $64 \%$ of its original vegetation (CORTELEZZI; MONDELLI, 2014), and sheep production decreased from 26.5 million head in 1991 to 6.4 million in 2019 (OPYPA, 2019). This reality influences, for example, the conservation of biodiversity and, in the case of sheep, the weeding of fields.

When threats influence ecosystem services, alternative states and benefit delivery trends are defined (Table 1), i.e., resource availability and likely changes. Perceptions between researchers and producers are divergent (Figure 4) in most ES. However, there are points in which they coincide, namely the behaviour of outcomes in the carbon sequestration delivery trend and the likely change and loss of livelihood. 


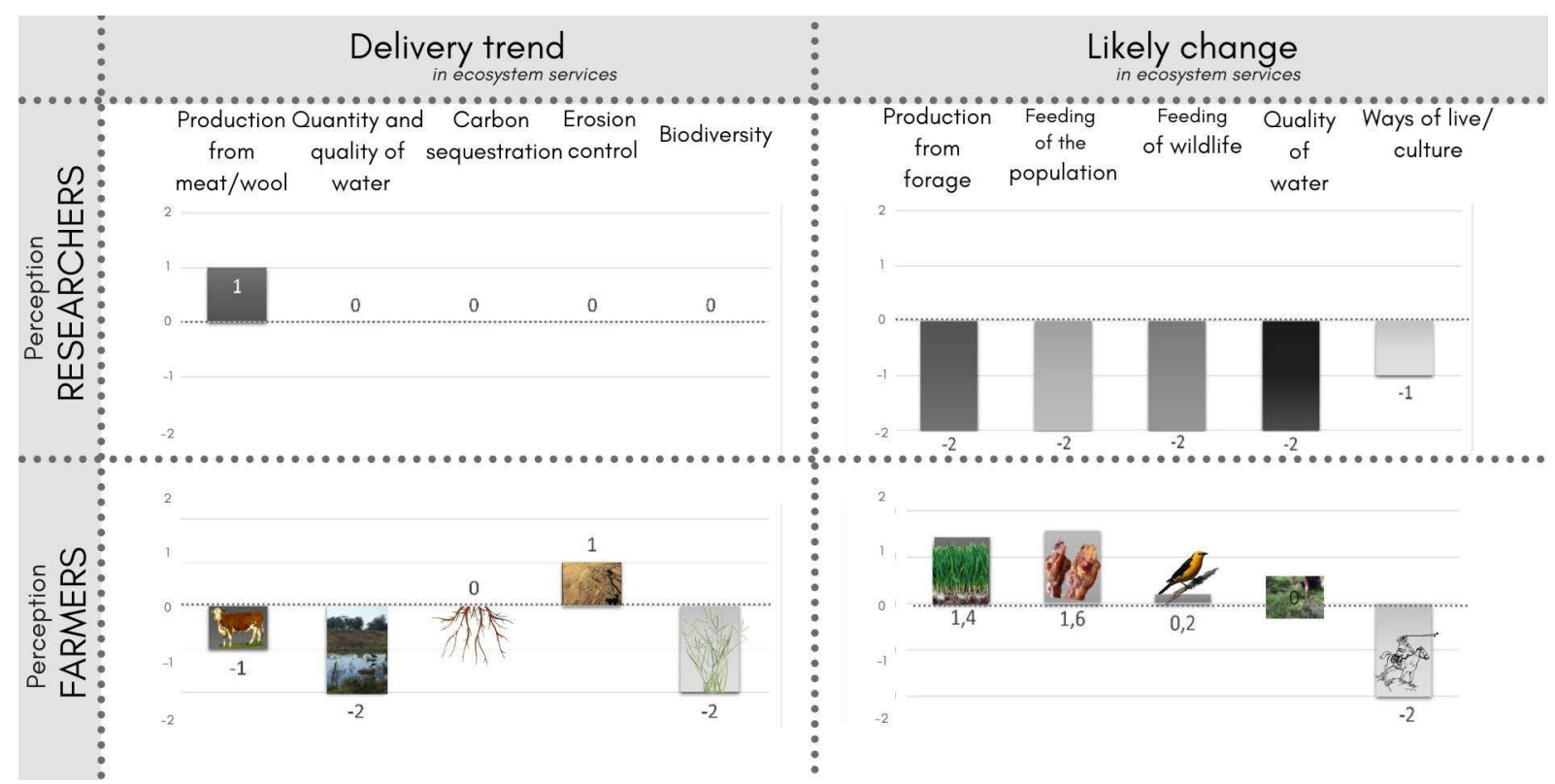

Figure 4 - Result of the trend in delivery (next 5 years) of the five primary ES targeted and the likely change (10 years) perceived by researchers and producers (where $2=$ large increase, $1=$ small increase, $0=$ no change, $-1=$ small decrease, -2 = large decrease).

Source: Created by author

The increase in beef and wool production would be due to the adoption and dissemination of better production practices, greater access to technical advice, and availability of information and connectivity by producers in the field. On the other hand, the producers' vision is that, in addition to the increase in agriculture, the intensification of sown pastures and feedlots also suggest an increase in grain production, increasing the supply of this type of foodstuff for the population and livestock.

\subsection{PERCEPTION OF THE MAIN ECOSYSTEM SERVICES AND THEIR DEGREE OF IMPORTANCE}

According to the Millennium Ecosystem Assessment (2003, p. 30), ES are categorised into provisioning, regulating and supporting and habitat and cultural services. The provisioning category [1] was shown to have the highest number of services rated as necessary in both the researchers and the producer group: production of fodder (cattle and sheep feed), meat, wool and honey, water quality and quantity, medicinal plants, and genetic material.

The researchers scored all ES with the same degree of importance (value 5), and this behaviour occurred in most of the countries where the methodology was applied (SCHOSSLER et al., 2021).

The issue of water, its quality and quantity, for people, animals, and beneficiaries further away, such as city dwellers, was one of the most important benefits for all groups. Its importance aligns with the IPCC findings (2021, chapter 8 ), which concludes with high confidence that human-caused climate change has driven detectable changes in the global water cycle. 


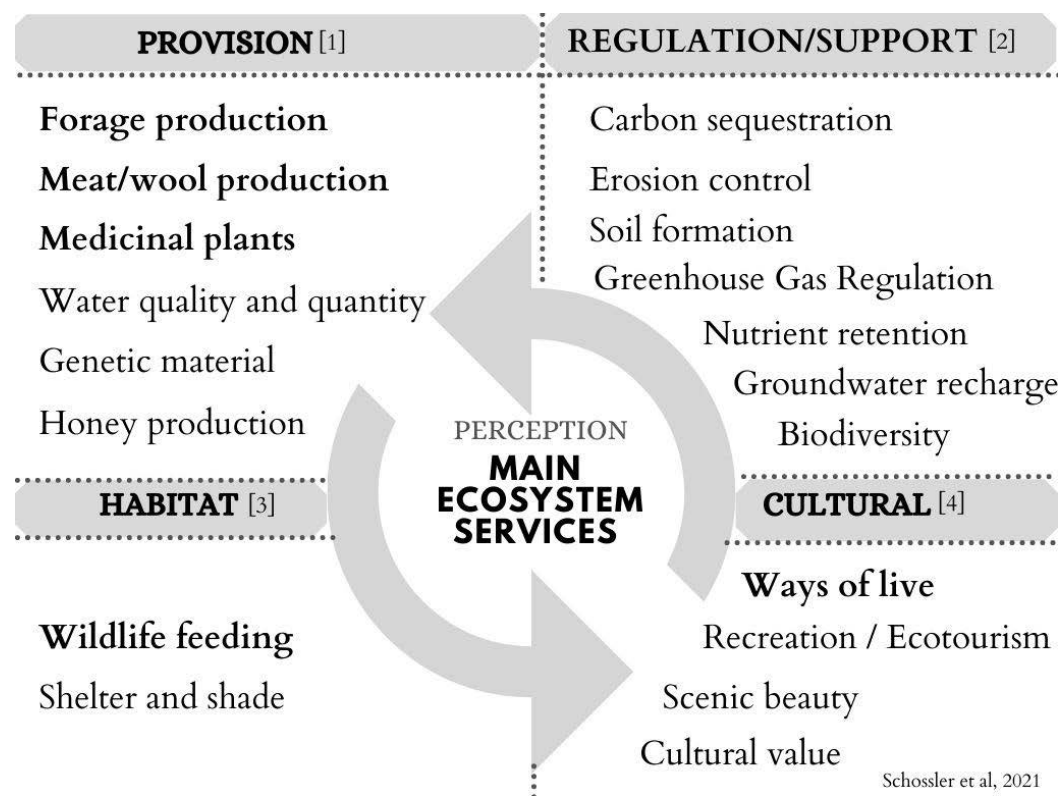

Figure 5 | Perception of importance of ecosystem services of Uruguay's natural grasslands subdivided into the four main groups (IPBES, 2015), Provisioning, Regulating and Supporting, Habitat and Cultural. According to the degree of importance (0-5), a) high degree (2.5-5.0); b) medium (0 - 2.5). Highlighted those that both groups cited.

Source: Created by author

Benefits that are more difficult to measure, such as biodiversity [2] and culture [4], are associated with habitat transformation, homogenisation, and disturbance (MODERNEL et al., 2016). Like this study, Cortés-Capano et al. (2020, p. 845) also revealed that landowners' management decisions and their primary needs are not primarily motivated by economic interests but also by cultural values, sense of place, relationship with nature, and traditional ranching. The main activity in the landscape of interest is extensive cattle ranching, which is traditionally associated with low productivity (OPYPA, 2017). However, a high cultural value is related to this type of ranching because the gaucho is the ecosystem manager (MODERNEL et al., 2018). Gorosábel et al. (2020) recently carried out an extensive literature review where it was found that studies related to values and immaterial, cultural contributions are scarce in the mentioned context.

On the impacts on soil conservation, both groups were clear that agriculture can maintain carbon sequestration and control erosion depending on the practices adopted. This is especially true when compared with overgrazing cases, which tend to be very common in traditional livestock systems. The benefits categorised as habitat [3] are forage for wildlife and shelter and shade for animals.

\subsection{CONSERVATION ACTIONS}

The actions noted that already occur in the territory of interest are related to technical and environmental assistance institutions (Snap and IPA) and the participation in development projects. This factor affirms the importance of governance processes in addressing conflicts of interest in using natural resources.

The producers' actions that are not occurring and are highlighted as necessary include the registration of native forests for tax exemption and the development of projects to promote better cattle ranching practices.

The positive impacts on nature include carbon sequestration, water quality, air purification, and the users and keeper's socio-cultural values in an integrated valuation of ecosystem services (MARTíNLÓPEZ et al., 2014) potentiates the success of projects and the application of recommended practices. 
This is possible because this approach considers, as in any rural development strategy, the producer and their objectives as a central figure in decision making (NABINGER et al., 2009).

Generating data based on the integration of local stakeholders, institutions and technicians, with participatory consultations makes it possible to obtain a product with a high level of consensus among all participants. An example of this approach is the application of the Methodology for the participatory evaluation of rangelands (PRAGA) in Uruguay (CORTÉS-CAPANO et al., 2020; FORMOSO et al., 2020).

\section{LESSONS LEARNED FROM THE METHODOLOGY}

The chosen area was suitable for two crucial aspects: homogeneity due to the same environment of natural grasslands with native riparian forests and the exact profile of the participants. There were productive discussions, given that they shared similar production challenges.

The inter-institutional nature of the work and the participation of the producers in other projects made it easier for the participants to perceive the importance of their contribution to the process. Returning the study results is essential for users to accept new participatory projects. In that case, a talk was presented at a cattle ranchers meeting, "Encuentro de Ganaderos", in October 2019, where a portion of the results was presented.

\section{From the Tessa methodology}

- Using the "alternative state": using this concept at the beginning of the engagement process was difficult for participants to understand. Therefore, it was decided not to present the "alternative state" map proposed in the Tessa guide. Instead, the alternative states emerged throughout the exercises, making the process easier.

- Regarding the quality of the map: the most user-friendly alternative for the producers was a printed satellite map from the Google Earth platform. For the producers' use, the document must contain the land use, the animal load, the floodable area, the agricultural area, and the surface soil area..

\section{Regarding the workshop methodology}

- Importance of sensitisation: the success of the work lies in the sensitisation of the stakeholders to the importance of activity results obtained. Important aspects utilised for this purpose were guaranteeing a publication with the data collected and the commitment to return the results.

- Number of participants: at most, 20 participants were divided into up to 5 working groups.

- Duration: based on the experience gathered in the other three countries, the total duration of the workshop of 5 hours achieves good results. However, it discourages participants before the end of the activities, which is crucial for finalising points of view. 


\section{CONCLUSIONS}

Identifying the benefits and threats of the natural grasslands with an ecosystemic vision of production and conservation with the participation of resource users and researchers influences the adoption of sustainable management and strengthens arguments for decision-makers. The results generated in the workshops achieved the objective of identifying the ecosystem services and threats perceived by producers and researchers.

According to the users, the impact of the lack of incentives and primary structure (energy, connectivity, schools) in the countryside for rural people has profound consequences on the generational changes of livestock raising in Uruguay, which has a combination of livestock production and citizen well-being unique in the world.

The richness of the work was in learning and using the innovative application of the participatory method in pilot form and integrating the opinion of the users to solve the problems at hand. In addition, territorial governance and the in-depth analysis of institutions, such as IPA and Snap, regarding the different topics in the CJG facilitated the optimal use and advancement of the methodology.

Recognising the limitations of case studies with participatory methodologies, we consider our results positive and the method replicable. We believe this method to apply to more producer groups to contribute to the development of public policies to encourage the conservation of natural grassland ecosystems.

\section{ACKNOWLEDGEMENTS}

To all the producers of Colonia Juan Gutiérrez and participants of the workshops and the NGO BirdLife International for their financial support.

\section{REFERENCIAS}

BÁEZ, M. Asociativismo de pequeños productores. Mendoza: Universidad Nacional de Cuyo, 2005, 9p.

BAEZA, S.; PARUELO, J. M. Land use/land cover change (2000-2014) in the Rio de la Plata grasslands: an analysis based on MODIS NDVI time series. Remote Sens, v. 12, n. 381. DOI: 10.3390/rs12030381, 2020.

BALDI, G.; PARUELO, J. M. Land-use and land cover dynamics in South American Temperate grasslands. Ecol. Soc., v. 13, n. 2, p. 6, 2008.

BALMFORD, A. et al. Bringing ecosystem services into the real world: an operational framework for assessing the economic consequences of losing wild nature. Environmental and Resource Economic, v. 48, p. 161-175, 2011.

BERRETTA, E. J. et al. "Campos in Uruguay,". In: Grassland Ecophysiology and Grazing Ecology. LEMAIRE, G. et al. (Ed.) (Wallingford-Oxon: CAB Intern), p. 377-394. DOI: 10.1079/9780851994529.0377, 2000.

BHAGABATI, N. K. et al. Ecosystem services reinforce Sumatran tiger conservation in land use plans. Biol. Conserv., v. 169, p. 147-156, 2014.

CASTILLO, D. et al. What role do social actors play in the context of ecosystem services? A review in areas of ecology and conservation biology. Sustentabilidade em Debate, v. 10, n. 1, p. 116-131. ISSN-e 2179-9067, Brasília-DF, 2019.

COMITÉ NACIONAL DE ESPECIES EXÓTICAS INVASORAS. Especies exóticas invasoras en el Uruguay. Montevideo: Unesco, 2014. 
CORTELEZZI, A.; MONDELLI, M. Censo General Agropecuario 2011: interpretación de los principales resultados y cambios observados. Montevideo: Anuario OPYPA, p. 471-490, 2014.

CORTÉS-CAPANO, G. et al. Degradación y gestión sostenible del campo natural en el Uruguay: resultados de una evaluación participativa en el norte del país. Montevideo, FAO, CAF y MGAP, 2020.

DAW, T. et al. Applying the ecosystem services concept to poverty alleviation: the need to references toolkit for ecosystem service site-based assessment 5 disaggregate human well-being. Environmental Conservation, v. 38, p. 370-379, 2011.

DÍAZ, S. et al. Set ambitious goals for biodiversity and sustainability. Science, v. 370, n. 6.515, p. 411-413, 2020.

DÍAZ, S. et al. Assessing nature's contributions to people. Science, v. 359, n. 6.373, p. 270-272, 2018.

FAGERHOLM, N. et al. Perceived contributions of multifunctional landscapes to human well-being: evidence from 13 european sites. People and Nature, v. 2, n. 1, p. 217-234. https://doi.org/10.1002/pan3.10067, 2020.

FORMOSO, D. et al. Degradación y gestión sostenible del campo natural en el Uruguay: resultados de una evaluación participativa en el sureste del país. Montevideo, FAO, CAF y MGAP, 2020.

GOROSÁBEL, A. et al. Insights for policy-based conservation strategies for the Rio de la Plata Grasslands through the IPBES framework. Biota Neotropica, v. 20 (suppl. 1), p. e20190902. https://doi.org/10.1590/1676- 0611-BN2019-0902, 2020.

GRIFFITH, G. E.; OMERNIK, J. M.; AZEVEDO, S. H. Ecoregions of Central and South America [GIS data]. U.S. EPA ORD NHEERL. Disponible en: http://ecologicalregions.info/htm/sa_eco.htm, 2011.

HANNAH, L.; CARR, J. L.; LANKERANI, A. Human disturbance and natural habitat: a biome level analysis of a global data set. Biodivers. Conserv., v. 4, n. 2, p. 128-155,1995.

HELLIWELL, J. et al. World Happiness Report 2021. Disponible en: https://happiness-report.s3.amazonaws. com/2021/WHR+21.pdf.

IPCC, 2021. Climate Change 2021: the physical science basis. Contribution of Working Group I to the Sixth Assessment Report of the Intergovernmental Panel on Climate Change [BERGER, S.; CAUD, N.; CHEN, Y.; CONNORS, S. L.; GOLDFARB, L.; GOMIS, M. I.; HUANG, M.; LEITZELL, K.; LONNOY, E.; MASSON-DELMOTTE, V.; MATTHEWS, J. B. R.; MAYCOCK, T. K.; PÉAN, C.; PIRANI, A.; WATERFIELD, T.; YELEKÇI, O.; YU, R.; ZHAI, P.; ZHOU, B (Ed.)]. Cambridge University Press. In Press, 2021.

LI, Y.; WESTLUND, H.; LIU, Y. Why some rural areas decline while some others not: an overview of rural evolution in the world. Journal of Rural Studies, n. 68, p. 135-143. https://doi.org/10.1016/j.jrurstud.2019.03.003, 2019.

MACHÍN, M. Taita: una cosechadora de cepillo de campo natural. Revista Plan Agropecuario, Recursos Naturales. Ed. 173, p. 54-55, 2019.

MARTÍN-LÓPEZ, B. et al.. Trade-offs across value-domains in ecosystem services assessment. Ecol. Indic., n. 37, p. 220-228, 2014.

MEDINA, S. et al. Restauración de Servicios Ecosistémicos en base a la implantación de Pasturas Nativas en el Área Protegida de los Montes Del Queguay. Revista INIA, n. 56, p. 43-47, 2019.

MILLENNIUM ECOSYSTEM ASSESSMENT. Ecosystems and Human Well-being: a framework for assessment (Island Press), 2003.

MILLENNIUM ECOSYSTEM ASSESSMENT. Ecosystems and Human Well-being, p. 3. Washington D.C.: Island Press, 2005.

MINISTERIO DE GANADERÍA, AGRICULTURA Y PESCA (MGAP). Resolución n. 1349/012. Creación de la Mesa de Campo Natural. Disponible en: https://www.gub.uy/ministerio-ganaderia-agricultura-pesca/institucional/ normativa/resolucion-1349012-creacion-mesa-campo-natural, 2012. 
MODERNEL, P. et al. Identification of beef production farms in the Pampas and Campos area that stand out in economic and environmental performance. Ecol. Indic., n. 89, p. 755-770. DOI: 10.1016/j.ecolind.2018.01.038, 2018.

NABINGER, C. et al. Produção animal em campo nativo: aplicações de resultados de pesquisa. In: PILLAR, V. P. et al. (Org.). Campos sulinos: conservação e uso sustentável da biodiversidade. Brasília: Ministério do Meio Ambiente, p. 175-198, 2009.

NABINGER, C. et al. Servicios ecosistémicos de las praderas naturales: ¿es posible mejorarlos con más productividad? Asociación Latinoamericana de Producción Animal, v. 19, n. 3-4, p. 27-34, 2010.

NISBET, E. K.; ZELENSKI, J. M.; MURPHY, S. A. Happiness is in our nature: exploring nature relatedness as a contributor to subjective well-being. Journal of Happiness Studies, v. 12, n. 2, p. 303-322. https://doi.org/10.1007/ s10902-010-9197-7, 2011.

OPYPA-MGAP. Características y resultados de la ganadería familiar en el Basalto y Sierra del Este. Línea de Base para la evaluación de impacto del proyecto GFCC, 2017.

OPYPA-MGAP. Situación y perspectivas de la cadena ovina, Anuario OPYPA. Disponible en: https://www.gub. uy/ministerio-ganaderia-agricultura-pesca/sites/ministerio-ganaderia-agricultura-pesca/files/documentos/ publicaciones/Situaci\%C3\%B3n\%20y\%20perspectiva\%20de\%20la\%20cadena\%20ovina.pdf, 2019.

PALACIOS, H. B. Análisis participativo de la oferta, amenazas y estrategias de conservación de los servicios ecosistémicos en la subcuenca “la Suiza” Chiapas, México, 2012.

PARERA, A.; PAULLIER, I.; WEYLAND, F. (Eds.). Índice de Contribución a la Conservación de Pastizales Naturales del Cone Sur (ICP). Una herramienta para incentivar a los productores rurales, 2014, 181 p.

PARUELO, J. M. et al. The grasslands and steppes of Patagonia and the Rio de la Plata plains. Phys. Geogr. South Am., p. 232-248, 2007.

PEH, K. S.-H. et al. Toolkit for Ecosystem 25 Service Site-based Assessment, Cambridge Conservation Initiative, Cambridge, 2013.

PEH, K. S.-H. et al. Toolkit for Ecosystem Service Site-based Assessment (Tessa). Version 2.0 Cambridge, UK. Disponible en: http://tessa.tools, 2017.

PÉREZ ROCHA, J. El estado del campo natural en el Uruguay. Montevidéu. FAO, MVOTMA e MGAP. https://doi. org/10.4060/cb0989es, 2020.

RAYMOND, C. M. et al. The farmer as a landscape steward: comparing local understandings of landscape stewardship, landscape values, and land management actions and land management actions. Ambio, v. 45, p. 173-184. https://doi.org/10.1007/s13280-015-0694-0, 2016.

RESTREPO-OSORIO, D. L. Ranching in the Floodplain of the Queguay River in Northwestern Uruguay. (Doctoral dissertation). The University of Kansas, 2020.

SCHOSSLER, D. S. et al. Livestock farmers and researcher's perceptions about ecosystem services provided by Rio de la Plata Grasslands. XXIV INTERNATIONAL GRASSLAND CONGRESS, 2021.

SCHOSSLER, D. Identificação de Serviços Ecossistêmicos de Campos Naturais no Bioma Pampa e Valoração do estoque de carbono do solo utilizando a Metodologia Tessa. (Tesis de Maestría) - Universidade Federal de Pelotas, Brasil, 113f., 2016.

SCHOSSLER, D. S. et al. Proyecto piloto de evaluación de servicios ecosistémicos en pastizales naturales en Entre Ríos, Argentina. In: VII CONGRESO NACIONAL SOBRE MANEJO DE PASTIZALES NATURALES X ENCUENTRO DE GANADEROS DEL PASTIZAL DEL CONO SUR VIRASORO. p. 91-91, 2016 (A). 
SCHOSSLER, D. S.; SFORZA, L.; ANGARITA-MARTINEZ, I. A. La percepción social de investigadores y productores con relación a los servicios ecosistémicos de los pastizales naturales de la zona de Paraguarí, Paraguay. In: VII CONGRESO ARGENTINO DE PASTIZALES NATURALES VIRASORO. p. 92, 2016 (B).

TALLIS, H.; POLASKY, S. Mapping and Valuing Ecosystem Services as an Approach for Conservation and Natural: resource management. Annals of the New York Academy of Sciences, v. 1.162, n. 1, p. 265-83. DOI: 10.1111/j.1749-6632.2009.04152.x 2009.

VIGLIZZO, E. F.; FRANK, F. C. Land-use options for Del Plata Basin in South America: tradeoffs analysis based on ecosystem service provision. Ecol. Econ., v. 57, p. 140-151. DOI: 10.1016/j.ecolecon.2005.03.025, 2006.

WEYLAND, F.; BARRAL, M. P.; LATERRA, P. Assessing the relationship between ecosystem functions and services: importance of local ecological conditions. Ecol. Indic., v. 81, p. 201-213. DOI: 10.1016/j.ecolind.2017. 05.062, 2017. 